\title{
THE NONMARKET ENVIRONMENT OF THE WINE INDUSTRY \\ IN THE REPUBLIC OF MACEDONIA: THE CASE OF WINES OF MACEDONIA ASSOCIATION (FROM MARKET RIVALS TO ALLIES IN THE NONMARKET ENVIRONMENT)
}

Siniša Zarić ${ }^{1}$, Igor Ilievski ${ }^{2}$

*Corresponding author E-mail: sinisha.zaric@gmail.com

\begin{abstract}
A R T I C LE IN F O
Original Article

Received: 09 February 2018

Accepted: 30 March 2018

doi:10.5937/ekoPolj1802503Z

UDC 34:663.21(497.7)

Keywords:

wine production, nonmarket environment, regulation, subsidies, professional networks

JEL: H23, L15, L51, K20 Q43.

A B S T R A C T

The production of wines contributes strongly to the overall export of Macedonia, having a big tradition and potentials for further development due to good climate and soil conditions. In the same time, the production of wine, in many countries, is one of the highly regulated sectors. Thus, there is a need for wine manufacturers to deal actively with the nonmarket environment and influence on regulatory legislation. Having in mind a big importance of the EU market for the export of Macedonian wines, there is a need for further harmonization with the EU regulation. Subject of this paper is a critical analysis of the economic policies in the field of agricultural production focused on the policy of subsidies. The aim is to show importance of having the active role of the wine producers in the nonmarket environment. Qualitative methodology is based on the experiences of the Wines of Macedonia (WOM) Association and, indicating the possibility of transforming the market rivals into nonmarket allies.
\end{abstract}

(C) 2018 EA. All rights reserved.

\section{Introduction}

Wine production in the Republic of Macedonia dates to the ancient times, but not until recently the country saw intensified worldwide recognition of its wines both in terms of export figures development as well as the awarded recognitions and accolades on all major wine competitions worldwide. The Republic belongs to the C3 area of the oenological map (www.wzw.tum.de/blm/alt/bmeier/pages/91zonen.htm), being ideal for viticultivation of the best quality red grapes.

With both production quantity and mainly quality of Macedonian wine increasing in the past decade (2006 - 2015), driving the successful development and modernization

1 Sinisa Zaric, Ph.D, Full Professor, University of Belgrade, Faculty of Economics, Kamenicka street 6, 1100 Belgrade,Serbia Phone: +381113021147, E-mail: sinisa@ekof.bg.ac.rs.

2 Igor Ilievski, Ph.D Candidate, European Center for Peace and Development, University for Peace, established by UN, Terazije 41, 11000 Belgrade, Phone:+38970337788, E-mail: iilievski@gmail. com, position: CEO of Green Cola Adriatic ( Macedonia street 3, 1000 Skopje, Macedonia). 
of the wine industry, the objective of this assignment is to analyze the successful implementation of nonmarket strategies by the main players in the industry, derived by their clear understanding of the overall nonmarket environment of the wine industry and its high importance for the office holders in the relevant government bodies.

The discussion topic in this article is to depict the nonmarket environment of the wine industry in the 2006-2015 period and analyze the implementation of relevant nonmarket strategy by the main industry players by creation of a trade association "Wines of Macedonia" (WOM) with main objective to accelerate the country bottled wine exports and represent a voice of the industry in dealings with the country relevant governmental bodies, international promotional agencies and the wine press worldwide. David Barons classic book "Business and Its Environment" and his "4 I's" model offers a theoretical framework for the analyses.

As we will see from the analysis presented in the following pages, the establishment of a relevant trade association "Wines of Macedonia", contributed to fast expansion of the wine exports, supported and funded by the Ministry of Agriculture, Forestry and Water economy (MAFWE) of Republic of Macedonia as well as by EU and USAID development programs resulting in more than $250 \%$ increase of the bottled wine exports in volume with even further positive influence of all. In the analyses, the need of developing the "bridging" character of this professional association is underlined and, also identified as one of the potential challenges in the WOM's activity.

According to the Macedonian Ministry of agriculture, forestry and water economy (MAFWE) Annual report 2015, Republic of Macedonia had 22.918 hectares of vineyards in 2015, producing on average $250 \mathrm{t}$ of grapes, of which on average $175 \mathrm{t}$ wine grapes, resulting in average annual wine production of $120 \mathrm{t}$ (1,2 million hectoliters).

Figure 1. Total vineyard area in Macedonia 2004-2009 (hectares)

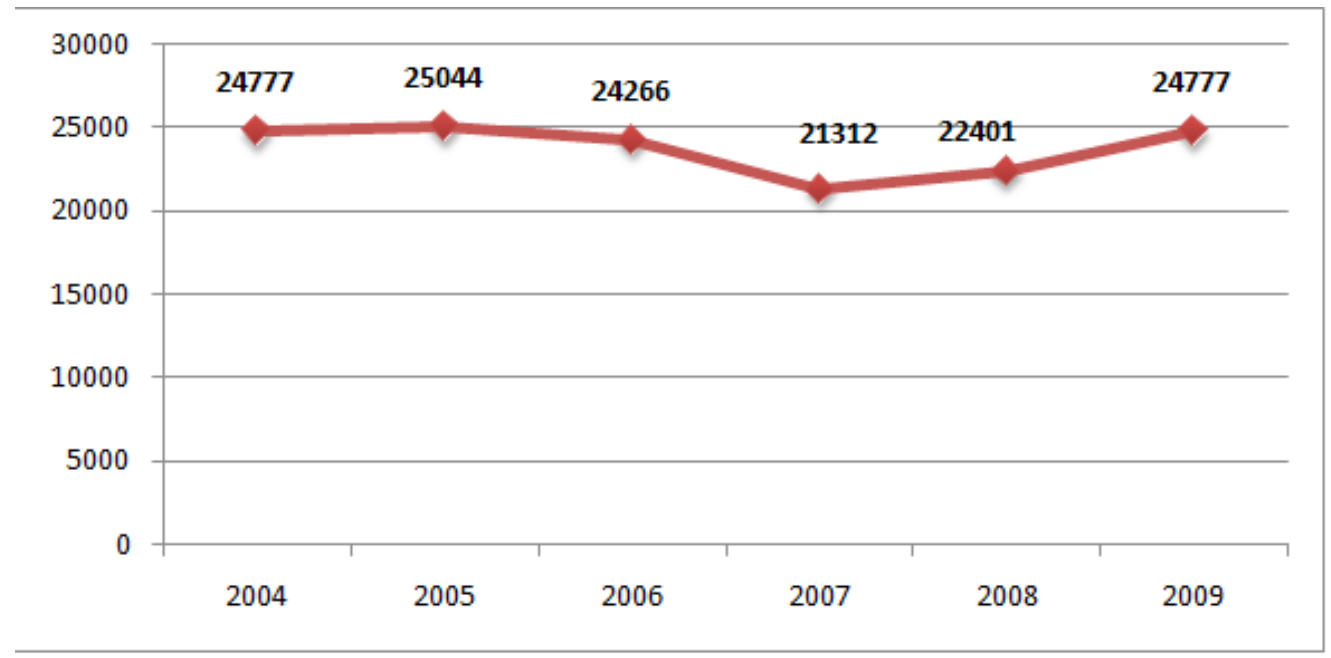

Source: State Statistical Office 
Furthermore, MAFWE annual report 2015 implies that the wine production in Macedonia in 2015 is carried out in 84 officially registered wineries with a total processing capacity of 2, 2 million hl and installed annual bottling capacity of around $650,000 \mathrm{hl}$. Although apparently insufficient, the bottling capacity is far from utilized as traditionally in the past several decades the Macedonian wine was predominantly exported as bulk.

More than $90 \%$ of the registered wineries are with capacity of less than $100.000 \mathrm{hl}$, while only 8 wineries are with capacity greater than $100.000 \mathrm{hl}$, reflecting the increased interest and development of the industry since 2003 when there were only 28 wineries, as many new small boutique wineries have been established since. Moreover, many of the wineries invested in sophisticated wine making equipment and technologies, so they can be more competitive on domestic and foreign markets focusing on highquality bottled wines made mainly from local grape varieties like "Vranec", "Kratosija", "Smederevka" and "Temjanika", but also from the international varieties like "Merlot", "Cabernet Sauvignon", "Pinot Noir", "Chardonnay", "Riesling", "Sauvignon Blanc" and others. Besides considering the local grape varieties as a kind of a national heritage, the wine producers must follow trend of the globalizing world (being export oriented). Storchmann (Storchmann, 2012) clearly states that the global market delivers a world of wine to ones door/table. Knowing that the wine is an experience good, Macedonian producers have to be aware of the strong role of experts and their reports - overcoming the information gap (Veseth, 2011). The trend is characterized by a strong convergence in the alcohol consumption patterns (Holmes, A.J. and Anderson, K., 2017) and globalization of preferences.

Out of the 1,2 million hl of wine produced annually, only $10 \%$ or $120.000 \mathrm{hl}$ is consumed in the country, while the rest being exported, amounting to annual value of 50 million EUR. The importance of wine production illustrates the fact that the economic impact varies from $17 \%$ to $20 \%$ of the entire agriculture GDP. Wines are the second largest agricultural exports good, after tobacco. EU is the key wine export destination, accounting for nearly $60 \%$ of the export volume in 2015 , followed by the CEFTA countries. Majority of the volumes are exported as a bulk wine, $87 \%$ in 2010 , with positive trend in the past years where this figure drops to $66 \%$ in 2015 and the rest $34 \%$ of the overall wine exports volume accounts to bottled wine.

Subject of this paper is a critical analysis of the economic policies in the field of agricultural production focused on the policy of subsidies. The aim is to show importance of having the active role of the wine producers in the nonmarket environment. Qualitative methodology is based on the case study of Wines of Macedonia (WOM) Association and, indicating the possibility of transforming the market rivals into nonmarket allies. The analytical framework in this paper is based on the analysis of Becker $(1983,1985)$ and Barron (2010). 


\section{Analysis of the wine industry environment (market and nonmarket) and methodology framework (the importance of the Baron`s contribution)}

The MAFWE National strategy for agricultural development 2014 outlines that after the tobacco production, the wine industry as the second biggest agricultural export sector of Macedonia. According to WoM (www.winesofmacedonia.mk/key-figures/) estimated the economic impact of the wine production to some $17-20 \%$ of the agricultural GDP. Approximately 20.000 households in Macedonia located across 15 municipalities (out of 85) grow grapes as main or additional income, representing an important asset of great political value, accounting for approximately 100.000 voters or $7 \%$ of the total voters.

The well-known conclusion of Stanford's professor David Baron that some companies could be very successful in the market, facing the strong competition and, in the same time, very unsuccessful in managing their relations with the non-market environment, made a strong impact not only within the academic communities, but in business world, as well. According to Baron (Baron, 2010) explanation of the rent chain concept, a large employment or stakeholder base (suppliers, customers, distributors, capital, communities) is potentially important asset whose value is depending on the number of people affected, their resources and their coverage of political jurisdictions, posing great importance on the Macedonian wine industry for the politics.

In addition, considering the overall political and economic situation in Republic of Macedonia in the past decade (2006-2015), with strong right wing populist government, an individual firm/winery couldn't freely or inconsequentially communicate its issues nor effectively state its interests in front of the government bodies.

During this period, besides the general approach in allocating the financial impulses that is a subject of our analyses, there were periodical measures which were either not long lasting (such as the decision to cover up to $20 \%$ of the expanses for marketing and packaging of bottles with wine, in 2012) or other measures, generally seeking a lot of administrative work for the producers and being hard for implementation. In the budget allocation, there was a line for subsidizing the cultivation of the vine plantations. The subsidies vary from $40,000 \mathrm{MKD} /$ ha to $15,000 \mathrm{MKD} / \mathrm{ha}$.

Table 1. Subsidies for upkeeping the vine plantations/per ha

\begin{tabular}{|c|c|}
\hline Land size (ha) & Subsidies (MKD/ha) \\
\hline From 0,2ha to 5 ha & 40,000 MKD \\
\hline From 5,1 ha to 30ha & 24,000 MKD \\
\hline From 30,1ha to 50ha & 12,000 MKD \\
\hline Over 50,1 ha & $4,000 \mathrm{MKD}$ \\
\hline
\end{tabular}

Source: According to Official Gazette of the Republic of Macedonia, No 16, 2015. (1 Eur - 61,2 MKD) 
The subsidies on total surface of wine plantations are distributed to legal entity. This redistributive measure of the government was created in order to subsidize the wine plantations up to 2 acres (consequently, gradually decreasing the subsidies for big wine producers, depending of the plantation size). The problem of the profitability of the small grape producers has been, according to the scholars articles ( Di Vita and D'Amico, 2013) frequently discussed. The result of this redistributive activity of the government was a further discouraging of the consolidation process. Finally, it affects the productivity and the efficiency of the use of technology - lowering the international competitiveness. On the contrary, in EU, the wealthiest countries received the major share of the subsidies, increasing the subsidies per bottle of wine to push the competitiveness of the European wine production. According to Anderson and Jensen (Anderson, K. and Jensen, H.G., 2016), the average subsidy per bottle of wine produced in the European Union member states is about $15 \%$ per bottle.

Also, concerning the subsidies, it is important to say that the other measures were taken on an ad hoc basis - making pressures on prices, attracting voters, etc. According to Benhabib and Przeworski (2006) (having in mind the difficult economic situation in the Republic of Macedonia), as the medians (specially, during recessions, after the global economic crisis, etc) are becoming poorer, the redistribution measures are getting stronger. Benhabib`s and Przeworski`s model could be named as a median-preferred model of redistribution. In order to understand the redistribution policy in the case of Macedonian wine producers, the general case could be described as a design of equilibrium redistribution that is fitting the preferences of the poor voters (the owners of the small plantations, in our case). Campante (2011) described it as the income effect - effects on the groups (groups of voters - small wine producers) who are more sensitive to, as Campante calls it, "generous transfers". On the other side, the indirect obstacles to the processes of consolidation of plantations, could have a negative impact on ROA (Return on Assets), thus, contributing to the lower competitiveness of the Macedonian wineries on the international markets.

The issues for the wineries i.e. the wine industry in general, where twofold:

- Issues concerning requirements towards the government institutions (MAFWE) for increased financial support for wine export promotion that the wineries where unable to appropriately cover themselves.

- Issues concerning imposing stricter regulation on the sourcing side by the government (price of grapes and terms of trade), thus negatively affecting the interests of the wineries, based mainly on incomplete information and populist agenda of the government.

As Baron (Baron, 2010) suggests, any firm has a choice between forming a coalition or acting unilaterally to address an issue and if the issue could increase industry demand, the firms in the industry are in a similar situation and therefore such issues are best addressed at industry level through associations. 
In April 2010, the leading export-oriented wineries decided to establish an association "Wines of Macedonia (WOM)". The main objective of the newly created association was to accelerate the overall development of the Macedonian wine industry through exports but also there was a need for stronger representation in dealings with the government institutions.

Very important aspect of the establishment of the association WOM is that on the domestic market the founding wineries are all fierce competitors fighting for the share of the market, but the overall industry development and their individual growth depends mainly on accelerating their export performance. Thus, as Baron (Baron,2010) suggests, on many issues firms market rivals may be firm's nonmarket allies, frequently working through a trade association to implement nonmarket strategies, which was proven by this case as well, as it will be explained in the text below.

Baron suggests the "4 I's" concept for the analysis of nonmarket issues, which states that the nonmarket environment of a company is characterized by the " 4 I's":

1. Issues as basic units of analysis,

2. Interests include individuals or groups with the stake in the issue,

3. Institutions provide arenas in which the interests influence the outcome on issues, and

4. Information pertains to what the interests and institutional officeholders know or believe about the issue and their development.

The "4 I's" framework was widely accepted and frequently discussed becoming a kind of "classic" formula for understanding the subject, such as the concepts of "4 P's" on marketing, SWOT and PEST in management, "5W's" in event management, and so on. Some of the authors launched a number of inspiring modifications and novelties. Thus, Bach and Allen (2010) proposed a slight modification of Baron's 4i's-framework while maintaining the basic premise of his issue-anchored approach. Like Baron, their (ia3) framework suggests that managers begin with issues and then proceed to identify the actors with a stake in the issue, their interests, the arena in which the issue unfolds, the information actors need to prevail, and other critical assets they can bring.

Both frameworks can be applied across a wide range of issues, contexts and industries, where Bach and Allen (Bach and Allen,2010) contend that issues can be transformed over time through framing, and that firms as well as other nonmarket actors can frame strategically in order to shape issues to their advantage, while Baron (Baron, 2010) lays down the concept of the life cycle stating that the nonmarket issues can progress through five stages: (1) issue identification, (2) interest group formation, (3) legislation, (4) administration, and (5) enforcement. 
Baron presents the structured pluralism approach to the nonmarket analysis of a business. Basically, it is conducted a study of:

- Interests of firms, individuals, interest groups, and how they are transformed into nonmarket action, as one foundation of nonmarket analysis and,

- The characteristics of the government institutions (administrative and regulatory agencies, legislatures, international accords), where in public policy the nonmarket action is transformed into outcome, as the other foundation of nonmarket analysis.

Also, an aspect involving political competition of opposing interests in an institutional arena is being considered by David Baron (Baron ,2010), where the nature of political competition on an issue is a function of the concentration or dispersion of the benefits and the costs of the alternative and although it focuses on the nature and not the outcome, it provides a context for formulating strategies, referred to as The WilsonLowi matrix. Lowi (Lowi,1964) distinguished three types of policy differences: distributive, redistributive and regulatory. Lowi (1979) analyzed the clientelism networks, describing the cases of agencies being captured by the interest groups. Thus, business associations have to formulate their strategies including regular relations with the regulatory bodies.

Wilson (Wilson, 1980) differentiated the policy issues based on the criteria whether the benefits and costs of the policy are concentrated or dispersed in the area. But, this very well-known types of policies where a subject of critique from the point of view of the existence of different issues seeking for a single continuum of policy instruments (Howlett, 2010). Within the continuum of the instruments choices, the governments could promote the use of the most coercive instruments that are available or move toward the minimally coercive ones. The so-called "Doern continuum" (Doern and Phidd, 1983) is illustrated in the Figure below.

Figure 2. The Doern Continuum



Source: Hawlett, 2010.

So, the relative success of the business associations, such as WOM (www. winesofmacedonia.com), in making a pressure or dealing with the regulatory bodies for the interest of the wine producers, is framed with the character of the government and the society in general.

In the economic theory the most significant is the contribution of the Nobel laureate Gary Becker (Becker,1985). Becker formulated four theorems. The theorem 1 defines that the groups that are becoming more efficient in producing political pressure could 
be able to decrease their taxes or increase their subventions. In the Corollary to the Theorem 1, Becker clarifies that the political efficiency of the group does not depend on its absolute efficiency (in controlling the opportunistic behavior of its members - in our case, of the members of WOM), but on its relative efficiency (compared with the efficiency of the other sectors associations, clubs and networks).

Furthermore, Baron (Baron, 2010) implies that frequently firms seek cover rather than visibility in their nonmarket environment so that their positioning is obscured from the view of the public, focusing on relationship building and lobbying. Going further, a firm has a choice between forming a coalition or acting unilaterally to address and issue. The former, as Baron explains, is the case if the firms in the industry are in similar situation and acting through a coalition will produce public good for all members. Moreover, for some firms, associations can also be a cost-effective means of achieving their interests, which they cannot pursue on their own.

Basically, according to Baron (Baron, 2010), we can distinguish between three generic nonmarket strategies, which are not mutually exclusive and can be used together to achieve synergies.

1. Representation strategies based on the consequence on constituents of government officeholders,

2. Majority building, focused on developing the needed votes in legislature,

3. Informational strategies, focused on providing information to government officeholders.

Baron 2010 stresses that lobbying as central component of most representation and informational strategies represents strategic communication of politically relevant information to government officeholders. Lobbying is being strategic in the sense of advocating one's position or countering the information provided by the other side.

\section{Implementation of the nonmarket strategy: Results of the analyses}

After the analysis of a nonmarket issue a strategy needs to be developed and implemented to tackle that issue, which Baron 2010 states that is the link between the objectives and the specific actions taken to achieve them, also considering the strategies of the other interests as well as the progress of the issue through the life cycle.

Considering the generic nonmarket strategies suggested and defined by Baron ( Baron 2010), a representation strategy is based on the connection between elected officeholders and their constituents, as they are interested in serving them since they want to be re-elected, implying in our case a significant weight of the "Wines of Macedonia" association by the officeholders, as it ultimately represented and could have impacted a big population of grape growers and overall stakeholders of the wine industry.

Furthermore, analyzing WOM position and interest through the Wilson-Lowi matrix, it suggests predominant use of the interest group politics of the association, by lobbying and providing technical and political information to the Ministry of Agriculture, forestry and Water Economy (MAFWE). 
WOM annual report 2015 states that on the field, WOM was clearly recognized by the government institutions as the voice of the wine industry, which enabled relevant access to the policy makers, thus lobbying on the respective wine and grapes legislation, enabling protection of the interests of the wine industry by:

- Minimizing the negative effects of legislation for the wine industry (the right wing populist government with absolute power in all institutions was continuously imposing legislation on expense of the industry).

- Increasing the positive impact for the industry and its overall rent chain by providing competent know-how on the relevant fields i.e. informational strategies.

The informational strategies as suggested by Baron (Baron, 2010), are based on the superior information that an interest group has about consequences of alternatives for constituents.

In the case of WOM, the expertise of its members was translated in providing information and know-how in wine sales and marketing and the distribution of funds by the government to accelerate the industry performance of the bottled wine exports, which in turn will result in higher revenues and income for the wineries and respectively higher benefits for the 20.000 grape growing families including the wider base of all industry stakeholders.

Figure 3. Wine export from Macedonia in $000 \mathrm{hl}$

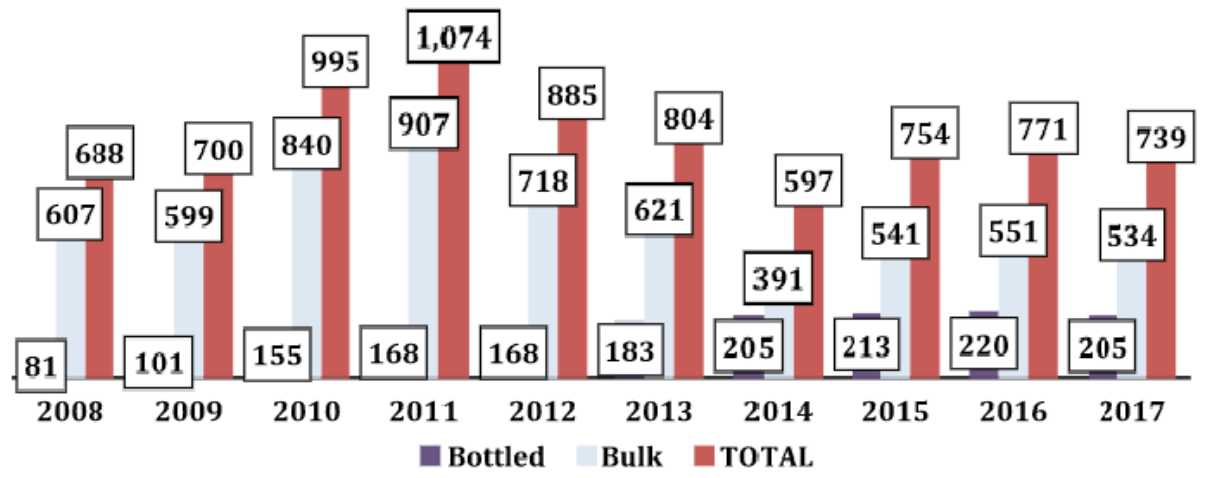

Source: Wine export, MAFWE, Dec.2017, Information on wine export per country, 2017

Before drawing conclusion from the presented nonmarket strategy of the Macedonian wine industry and its implementation, we must point out the actual results against the initially set targets of WOM to act as an industry voice in the dealings with the government bodies and increase the bottled wine exports, especially considering its relevance and overall importance as described in the previous pages. Therefore, we will look into two key performance indicators of WOM, the bottled wine exports and the obtained thirdparty funding for its promotional activities, presented in the figures below. 
Figure 4. Total wine export per year

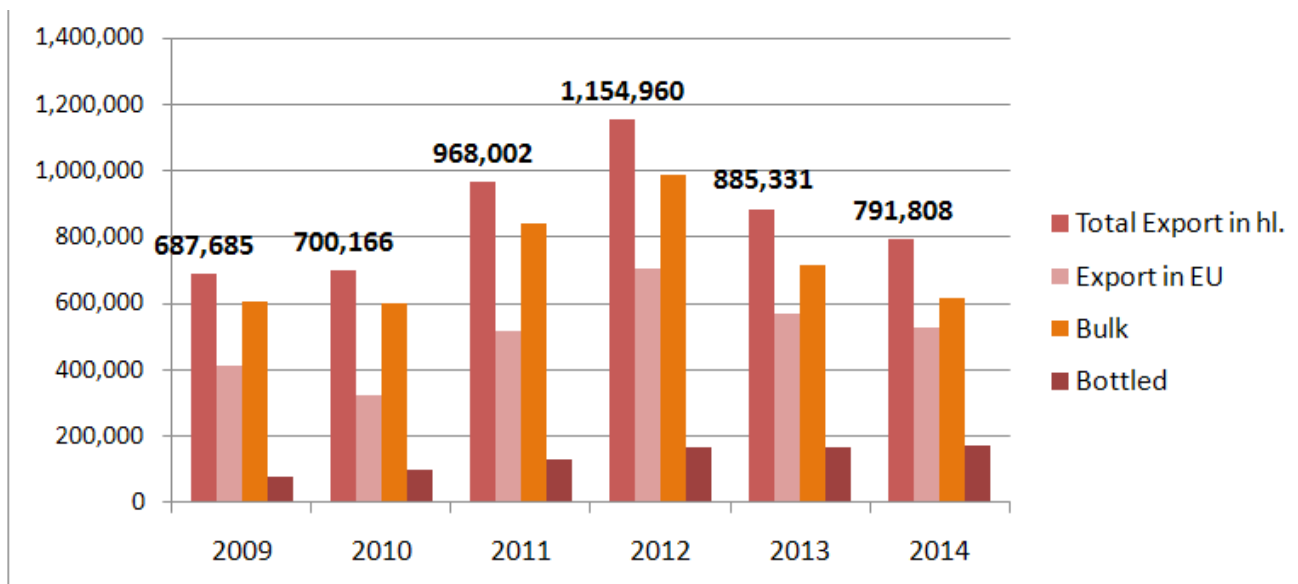

Source: State Statistical Office of the Republic of Macedonia, Wine in figures

(http://www.stat.gov.mk/ZaVinoto en.aspx), reviewed on 10.06.2016.

For the overall results, it is important to point that the share of the domestic, Macedonian, market, in wine sales is just $15 \%$.

Figure 5. Export of bottled wine from Macedonia

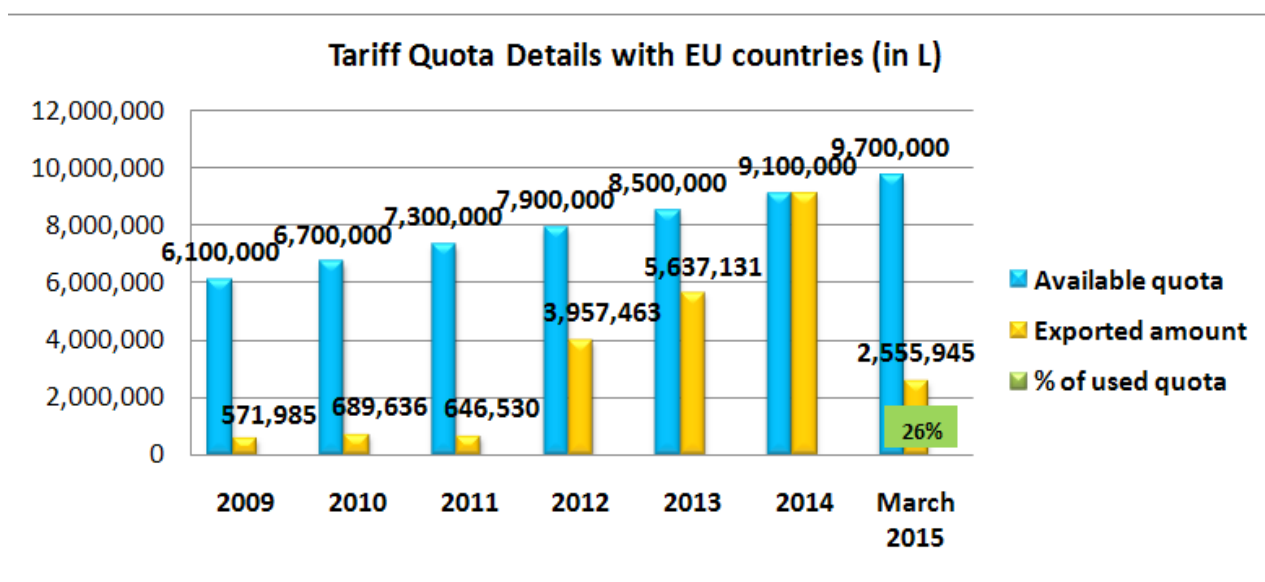

Source: Taxation and customs union, Tariff quota details

(http://ec.europa.eu/taxation customs/dds $2 /$ taric/quota tariff details.jsp?Lang=en\&QuotaAuthorities=false \& StartD ate $=2015-01-01 \&$ ContextPath $=\&$ Code $=091558$ ), reviewed on 08.07.2016.

The data from the MAFWE annual report, shows that beside the volatile and unpredictable evolution of the bulk wine exports, the bottled wine exports increased more than 2,5 times in the observed period, from $81.000 \mathrm{hl}$ in 2008 to $213.000 \mathrm{hl}$ in 2015 , clearly reflecting the overall efforts, including WOM role in achieving these results.

According to WoM (www.winesofmacedonia.mk/key-figures/), still $60 \%$ of the production is sold in bulk, and only $40 \%$ are products of bottled wine. 
Figure 6. Wine sales breakdown per category (in \%)

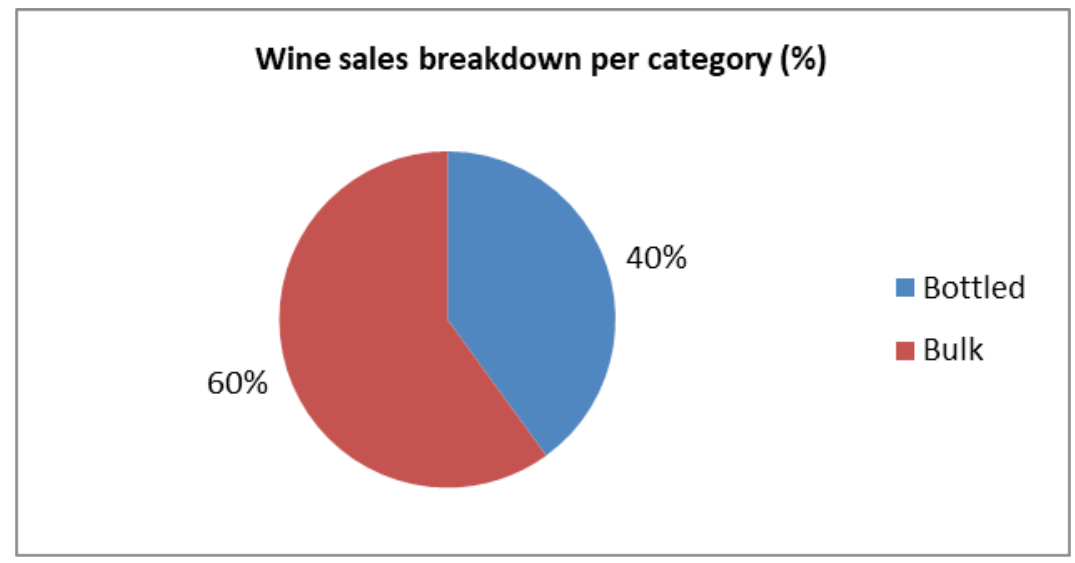

Source: Own estimation based on WoM figures

In addition to the individual funding by the wineries and their respective capabilities in the marketplace, WOM strategy in the nonmarket environment i.e. the MAFWE institutional arena, competed with various interest groups, mainly food producing associations, farmers unions and trade associations. As we can see from the figures below, WOM managed to provide sustainable funding for its activities, competing successfully, for the funding of its export promotions.

Table 2. Financial support for wine export promotional activities

\begin{tabular}{|c|c|c|c|c|c|}
\hline $\begin{array}{c}\text { WOM export promo } \\
\text { activities funding }\end{array}$ & $\mathbf{2 0 1 1}$ & $\mathbf{2 0 1 2}$ & $\mathbf{2 0 1 3}$ & $\mathbf{2 0 1 4}$ & $\mathbf{2 0 1 5}$ \\
\hline $\begin{array}{c}\text { CBI (Dutch promotional } \\
\text { agency) }\end{array}$ & 30.000 & 40.000 & 50.000 & 50.000 & 65.000 \\
\hline $\begin{array}{c}\text { MAFWE (Ministry of } \\
\text { agriculture) }\end{array}$ & 0 & 0 & 125.000 & 200.000 & 225.000 \\
\hline TOTAL in EUR & $\mathbf{3 0 . 0 0 0}$ & $\mathbf{4 0 . 0 0 0}$ & $\mathbf{1 7 5 . 0 0 0}$ & $\mathbf{2 5 0 . 0 0 0}$ & $\mathbf{2 9 0 . 0 0 0}$ \\
\hline
\end{tabular}

Source: WOM Annual Report 2015, pp 4-6

WOM, despite the initial slow start with the MAFWE in terms of building credibility and initial providing of information, in the years ahead clearly managed to secure sustainable funding of the export promotional activities, proving successful implementation of its nonmarket strategy. Analyzing the experiences of the Italian wine industry, one of the most advanced in the world, Odorici and Corrado (Odorici and Corrado, 2004), from the University of Bologna, pointed the importance of the intermediaries, on one side (still not of such an importance in the wine sector of Macedonia) and the associations and social networks. The role of the intermediaries is growing (from publishing wine guides to doing rankings), but the social networks and associations, such as WOM, could successfully manage the relations between the wine producers and the intermediaries. Having this perspective, WOM is expected to play a significant role (together with the growing importance of the intermediaries) in designing the generic framework of 
comparability. WOM could be concerned as a kind of the instrument that is increasing the social capital of its members, but also of the community. According to Van Shaik (Van Shaik,2002), participation in professional association could be understood as one of the dimensions of social capital. It is important to refer to Putnam`s (Putnam,2000) dichotomy of social capital. Namely, Putnam is distinguishing the so-called bonding and bridging social capital. The former could produce some negative impacts on the society (finally, to its members). Following this theoretical approach from the social capital theory, WOM members have to be aware of the problem and create their strong relations with the other players on the business and political markets.

As we can conclude from the analysis of the nonmarket strategy of the main players in the wine industry of Republic of Macedonia as well as the presented results against the main objectives, the establishment of the trade association "Wines Of Macedonia" contributed to the rapid development of the bottled wine exports supported by the relevant government institutions and foreign support organizations benefiting the wine producers performance at first, but also having even further positive impact on all industry stakeholders.

\section{Conclusions}

The wine production sector is becoming one of the fast-growing industries in Macedonia, producing very significant effects on GDP, employment, and export results. Wine industry representatives are facing a number of challenges coming from the nonmarket environment: from political and governmental bodies, legislation, and regulatory environment. Being aware that some company could have a good market results and in the same time not always ready to face the impacts coming from the nonmarket environment, the new association, WOM, has been created. The framework of the analyses was given in the Baron`s book on business and its environment.

The practical results, achieved in the last few years are positive. Although the number of the members in the association is not large (ten companies out of total of 84companies), they represent all the leaders on the wine market. Possible enlargement of the WOM could lower the marginal deadweight costs (according to Becker) of subsidies and taxes. The WOM members have to follow Becker's approach in analyzing the impact of deadweight costs on pressure, subsidies and taxes. Deadweight cost discourages pressure by the subsidized groups, and, vice versa, the groups of taxpayers are strengthening the pressure (Becker, 1983).

The role of WOM and the players on the nonmarket environment must be reconsidered from the international point of view. The domestic market is highly competitive, too. Besides the fact that almost $60 \%$ of the bottled wine from Macedonia is exported on the EU market, it is important to have in mind that from all export to EU, more than $81 \%$ of the bottled wine goes to the markets of Croatia and Slovenia. As the tradition of Macedonian wines in ex-Yugoslav countries is very long, it means, in fact, that the wine producers have to make stronger promotional efforts to enter other markets of 
the globalized world (Hussein et al, 2007). Knowing that the customs tariffs do not make any more so strong barriers in protecting the markets, it means that WOM and other players have to face the growing non-customs protectionist measures or know the characteristics of different nonmarket environments of the potential markets, even the changes emerging with the Internet trade (Wiseman, 2004). The wine market reflects the asymmetry (Kobrin,2015) that exists between the integrated international economy and the fragmented nonmarket environment.

As it is shown via documentary evidence from France, Italy, Romania and Spain (Itcaina et al, 2016), the growers have to face the demand on the global market. For Macedonian (and other producers in the Region), it could be very important to study the changes in the EU's regulation of the wine .especially after 2008, turning from the supplydriven to demand -driven measures. It has to be aware of the long-standing process of regulatory changes in Europe (Gaeta and Corsinovi,2014), lasting half a century (with major changes in adopted in2008) with the intention of reducing the redistributive role. Besides the fact that even the EU market could not be considered as a pure "monolith market" (Mitchell, 2016) the general trends in supporting wine production could be observed. The focus of the interventions passed from reducing subsidies for vine growing and distillation to so-called "microeconomic support" offered to wine manufacturers and recognized wine regions. This experience could mark the future activity of WoM members. Finally, the WOM Association has to communicate with other player in the nonmarket environment in order to avoid the trap of the bonding social capital creation.

\section{Conflict of interests}

The authors declare no conflict of interest.

\section{References}

1. Anderson, K. and Jensen, H.G. (2016). How Much Governmental Assistance Do European Wine Producers Receive?. Journal of Wine Economics, 11(2), 289-305, American Association of Wine Economists, New York, US.

2. Baron, D. P. (2010). Business and Its Environment. 6th Edition. Pearson Prentice Hall, Upper Saddle River, New Jersey, US.

3. Bach, D., and Allen, D. B. (2010). What Every CEO Needs to Know about Nonmarket Strategy. MIT Sloan Management Review, 51(3), 41-48, MIT, Cambridge, US.

4. Becker, G. (1983). A Theory of Competition Among Pressure Groups for Political Influence. The Quarterly Journal of Economics, 98 (3), 371-400, Oxford University Press, Cambridge, US.

5. Becker, G.S. (1985). Public Policies, Pressure Groups and Deadweight Costs. Journal of Public Economics, 28, 329-347, University of Chicago Press, Chicago, US. 
6. Benhabib, J., Przeworski, A. (2006). The Political Economy of Redistribution Under Democracy. Economic Theory, 29 (2),. 271-290, Springer, Berlin, Germany.

7. Campante, F.R. (2011). Redistribution in a Model of Voting and Campaign Contributions. Journal of Public Economy, vol. 95, pp. 646-656, Elsevier, Amsterdam, Netherlands.

8. Doern, G. B. and Phidd, R.W. (1983). Canadian Public Policy: Ideas, Structure, Process. Mathew.

9. Di Vitta,G., D`Amico, M. (2013) Origin Designation and Profitability for Small Wine Grape Growers:

10. Evidence from a Comparative Study, Economic of Agriculture, No. 1, 7-24, Institute of Agricultural Economics, Belgrade, Serbia.

11. Gaeta, D. and Corsinovi, P., (2014). Economics, Governance, and Politics in the Wine Market: European union Developments. Palgrave Macmillan, Basingstoke, United Kingdom.

12. Hawlett, M. (2010). Designing Public Policies: Principles and Instruments. Routledge, Abingdon, United Kingdom.

13. Holmes, A. J., and Anderson, K., (2017). Convergency in National Alcohol Consumption Patterns: New Global Indicators. Journal of Wine Economics, 12(2), 117-148, American Association of Wine Economists, New York, US.

14. Hussein, M., Cholette, S. and Castaldi, R.M. (2007). Analyses of Globalization Forces in the Wine Industry: Implications and Recommendations for Wineries. Journal of Global Marketing, 21(1), 33-44.

15. WOM (2016). Annual report 2015, WOM, Skopje, Macedonia.

16. Itcaina, X., Roger ,A. Smith, A., (2016). Varietals of Capitalism - A Political Economy of the Changing Wine Industry. Cornell University Press, Ithaca, New York, US.

17. Kobrin , S.J. (2015). Is a Global Nonmarket Strategy Possible? Economic Integration in a Multipolar World Order. Journal of World Business, 50(2), 262-272, Elsevier, New York, US.

18. Lowi T. (1964). American Business, Public Policy. Case-Studies, and Political Theory. World Politics, 16, 687-91, Cambridge, United Kingdom.

19. Lowi, T. (1979). The End of Liberalism: The Second Republic of the United States, Norton, New York.

20. MAFWE (2016). Annual report on agriculture and rural development for 2015, MAFWE, pp. 58-61. Skopje, Macedonia.

21. MAFWE (2014). National strategy for agriculture and rural development 2014-2020, MAFWE, 84-85. Skopje, Macedonia.

22. Mitchell, L. (2016). Demand for Wine and Alcoholic Beverages in the European Union - A Monolith Market?. Journal of Wine Economics, 1 (3), American Association of Wine Economists, New York, US. 
23. Odorici, V., Corrado, R., (2004). Between Supply and Demand: Intermediaries, Social Networks and the Construction of Quality in the Italian Wine Industry. Journal of Management and Governance, 8 (2), 149-171, Springer, Berlin, Germany.

24. Putnam R., (2000). Bowling Alone: The Collapse and Revival of American Community. Simon \& Schuster Paperback, New York, US.

25. Storchmann, K., (2012). Wine Economics. Journal of Wine Economics, , 7(1), 1 -33, American Association of Wine Economists, New York, US.

26. Van Shaik, T. (2002). Social Capital in the European Values Study Survey. Available at: www/oecd.org/innovation/research/2381883.pdf.

27. Veseth, M. (2011). Wine Wars: The Curse of the Blue Nun, the Miracle of Two Buck Chuck, and the Revenge of the Terrorists. Rowman and Littleheld, Lanham, MD, US.

28. Wilson, J. Q. (1980). The Politics of Regulation, Basic Books, New York, US.

29. Wiseman, A.E. and Ellig, J. (2004). Market and Nonmarket Barriers to Internet Wine Sales: The Case of Virginia. Business and Politics, 6 (2), Article 4., Cambridge University Press, Cambridge, United Kingdom

30. Available at: www.winesofmacedonia.mk/key-figures/, Accessed on December 22, 2017.

31. Available at: www.slvesnik.com.mk/issues/ afd4bad4215d44aa866ec0bd94d0e23pdf, Accessed on January 8, 2018.

32. Available at: http://www.mzsv.gov.mk/files/2015_Godisen $\% 20 \% 20$ izvestaj\%20za\%20zemjodelstv o\%20i\%20ruralen\%20razvoj.pdf, Accessed on October 16 th 2017.

33. Available at: http:/www.mzsv.gov.mk/NSZRR\%202014-2020.pdf, Accessed on October 16th 2017.

34. Available at: http://www.wzw.tum.de/blm/alt/bmeier/pages/91zonen.htm, Accessed on February, 08th 2017. 